\title{
The Anthropocene Consensus
}

\section{Transforming International Politics in the Age of Global Existential Threats}

\author{
Yevgeny I. Uchaev
}

\author{
Yevgeny I. Uchaev \\ MGIMO University of International Relations, Moscow, Russia \\ School of International Relations \\ MA student \\ ORCID: 0000-0002-4359-4203 \\ E-mail: eugeneuchaev@gmail.com \\ Address: 76 Vernadsky Prospect, Moscow 119454, Russia \\ DOI: $10.31278 / 1810-6374-2021-19-3-206-227$
}

\begin{abstract}
Humanity is facing the highest risk of global existential catastrophe in its history. What should be done to ensure effective international cooperation for the sustainable survival of humankind? The article posits that the main obstacles to international cooperation lie in the field of ideas and mentality. To overcome these obstacles, a new unifying metanarrative is proposed, the Anthropocene consensus. It means taking human survival not just as a goal or interest, but as an ethical Absolute, which serves as a reference point for assessing all other value systems. Since different forms of social organization, including at the international level, are unequal in terms of their impact on the prospects for human survival, the Anthropocene consensus implies certain principles of the global socio-political order: a non-absolute nature of sovereignty, a dialogue of countries with different political regimes, justice, and the priority of global security over national security. The conclusion suggests that the Anthropocene consensus has a reasonable chance of theoretical and practical success.
\end{abstract}


Keywords: Anthropocene, ethics, existential risk, grand narratives, postmodernism, survival of humanity, values.

I $\mathrm{n}$ 1947, the Bulletin of the Atomic Scientists launched the Doomsday Clock, a symbol showing how close humanity has come to a global disaster, according to the organization's experts. In 2020, the Bulletin announced that the hands of the Clock would be moved to 100 seconds to midnight - the closest to an "Armageddon" in its history (Cramer, 2021). And back in 2006, the authors of the Stern Review on the Economics of Climate Change estimated the probability of human extinction in the 21st century at 9.5\% (UK Treasury, 2006, p.47). Although both these estimates can be criticized for bias and alarmism, as well as for methodological problems, they are nevertheless indicative of one undeniable fact-since the middle of the 20th century, the level of existential risk ${ }^{1}$ for humanity has increased significantly.

While earlier the threat of complete human extinction came only from supervolcano eruptions, the fall of large asteroids or other natural events-quite rare and therefore unlikely in the foreseeable future-in the second half of the last century anthropogenic existential threats were added to this list: a nuclear war first, then the catastrophic consequences of climate change, and now new risks associated with the development of emerging information and biotechnologies (Ord, 2020). As a result, today humanity is perhaps in the most vulnerable state in its entire history. Oxford philosopher Toby Ord has called this condition and the corresponding historical era "the Precipice," defining it as "the time where humanity is at high risk of destroying itself" (Ibid., p. 33).

There is one interesting coincidence worth noting. According to the growing academic consensus, simultaneously with "the Precipice" a new era has begun on the geochronological scale-the Anthropocene,

Terminological note: the terms 'existential risk' and 'existential threat' are used interchangeably with regard to different sources of danger. If the probability of a catastrophe is also implied, only the term 'existential risk' is used. It should also be borne in mind that throughout the article risks/ threats to the whole of humanity, not local ones are meant (including when the word "global" is not used). 
in which humanity has become one of the main drivers of geological processes on Earth (Zalasiewicz et al., 2019). The middle of the 20th century is considered the most likely beginning of the Anthropocene since it coincides, first, with the start of nuclear tests causing an increased concentration of radionuclides in geological sediments, and, second, with the beginning of the so-called Great Acceleration, that is, a rapid economic and demographic growth in developing countries, which has caused a sharp increase in the consumption of natural resources and has intensified human impact on global natural processes (Ellis, 2018, pp. 52-74). But is the simultaneous start of the Anthropocene and "the Precipice" a mere coincidence?

Ord believes it is. "They might both officially start with the first atomic test, but this would be for very different reasons" (Ord, 2020, p. 33). However, it seems that there is a deep interconnection between existential risks (not necessarily anthropogenic) and the scale of people's influence on nature. Firstly, as Earth System Science studies indicate, the large-scale influence of people on geological and biological processes (the Anthropocene criterion) was one of the reasons for the increase in the level of existential risk (the Precipice criterion). For instance, according to the "planetary boundaries" concept, formulated by a group of scientists in 2009, due to the human influence nine key indicators of the state of the Earth System-the level of $\mathrm{CO}_{2}$ in the atmosphere, the degree of biodiversity, ocean acidification, etc.-may exceed critical values, thus pushing the state of the Earth out of the "safe operating space," that is, favorable natural conditions in which humanity has been living for the last ten thousand years (Rockström et al., 2009).

Secondly, the growth of technological potential, which creates the risk of self-destruction by the human race (the Precipice criterion), also adds to a large-scale influence on nature (the Anthropocene criterion). Importantly, this influence can be used, among other things, to prevent natural existential threats. Perhaps the most vivid example is rocket technology, which can not only condemn humanity to a nuclear Armageddon, but also protect it from asteroids.

So, the interconnection described above can be summarized as follows: if "the Precipice" is a period characterized by a high level 
of existential risk, then the Anthropocene is an era when humanity acquires the ability to significantly influence the level of existential risk to its existence (by both increasing and reducing it). Times of increased existential risk, similar to "the Precipice," probably happened before too, for example, some seventy thousand years ago, when, according to some estimates, the eruption of the Toba Supervolcano in Indonesia put humanity on the verge of extinction, causing its population to shrink by 96 percent from approx. 100,000 to 4,000 (Global Challenges Foundation, 2016). But while in the past the survival of humankind depended almost completely on a happy turn of events, now, in the Anthropocene era, much (albeit not all) depends on our choices and actions. What should our choices be? This article is an attempt to outline the answer to this question. The first two sections identify the major challenges and obstacles to the effective fight against global existential threats, section three proposes a possible solution and section four tries to assess its plausibility.

\section{ADDRESSING GLOBAL EXISTENTIAL THREATS}

Most studies of existential risk have a standard logic: the fight against existential threats is a global public good, which raises the problems of free riding and coordination among independent actors. Moreover, it is a transgenerational public good, and the groups most interested in providing it (future generations) simply do not have the opportunity to influence the decisions adopted today. Finally, some forms of cognitive bias, such as accessibility heuristics and scope neglect, prevent people from fully realizing the extent and urgency of existential threats (Bostrom, 2013, pp. 26-27; Global Priorities Project, 2017, pp. 11-12).

However, such rationalist explanations (albeit implying only limited rationality as indicated by the reference to cognitive bias) in this case seem obviously insufficient. Global existential risks are, by definition, a threat to the very existence of each actor without exception. Therefore, their reduction should be clearly recognized by all states and non-state actors as an unquestionable common interest. John Herz wrote about this back in 1957 as he pondered over the influence of nuclear weapons on international relations: "Now that destruction threatens everybody, 
in every one of his most intimate, personal interests, national interests are bound to recede behind-or at least compete with-the common interest of all mankind in sheer survival" (Herz, 1957, p. 492).

In part, this has happened: the nuclear factor has changed the nature of great-power relations significantly (Jervis, 1989), and the prevention of nuclear war has become a special, exceptional priority in relations between the USSR/Russia and the United States. At the same time, changes do not look irreversible even in the nuclear realm, since attempts to ensure nuclear security unilaterally are quite regular: one can recall both Reagan's first term with his SDI program and the Trump administration's recent attempts to undermine arms control regimes. As for other areas associated with high existential risk, such as climate change or biosecurity, sustainable and sufficient international cooperation is still nowhere in sight. What is the reason for this?

It seems that the main reasons lie not in the field of material interests and pragmatic considerations, but in the field of ideas, culture, and mentality.

Firstly, there are no universal values in a materially global and interdependent world. So it is the ideological and value heterogeneity of the leading world players that is the main obstacle to cooperation and the source of conflict (Safranchuk, 2020; Safranchuk and Lukyanov, 2021). The latest conceptual documents adopted in Russia and the United States clearly reflect this heterogeneity. The Biden administration's Interim National Security Strategic Guidance gives priority to protecting and promoting "the democratic values at the heart of the American way of life" (Interim National..., 2021, p. 9), and the new National Security Strategy of the Russian Federation pays special attention to "protecting traditional Russian spiritual and moral values" from attempts to "westernize" and erode them (RF National Strategy, 2021, pp. 34-38).

Secondly, it is indeed very difficult for modern people to grasp the existential nature of some global threats (and this is not a truism as it may seem at first glance). The fact is that modernity is an era of indefinite temporality (Foucault, 2009/2004, pp. 259-260; Habermas, $1987 / 1985$, pp. 5-11), and, therefore, the possibility of the "end of times" 
as a result of an existential catastrophe is somewhat "unthinkable" for modern people, since it goes against one of the fundamental principles of their worldview (Latour, 2017, p.194-199). This fact explains not only the individual, but also the social neglect of existential risks, since the same basic assumption about the infinity of time underlies the logic of all key present-day institutions, including the modern (Westphalian) state (Foucault, op.cit; Hamilton, 2018) and capitalism (Sewell, 2008, pp. 519-527). For these institutions, recognizing the finite temporality implied by global existential threats would mean questioning their own raison d'être. ${ }^{2}$

The above arguments thus show that changes at the level of ideas and mentality are essential to effectively counter global existential threats. Humanity needs a unifying idea that would clearly and unambiguously establish finite temporality.

\section{SEARCH FOR A UNIFYING IDEA}

Formulating such a unifying worldview system is not an easy task, because the "big ideas" that various actors and political forces advance today have exhausted their potential for expansion. This is true of both "democratic and human rights consensus" Biden is seeking to revive, and the "sovereign-traditionalist consensus" Russia is trying to propose as an alternative.

In a situation where Eastern European countries, with the approval of a large part of their population, are moving further away from the accepted standards of liberal democracy, a personalist regime, whose legitimacy is based on socioeconomic achievements (BBC, 2021), is consolidating in China (Gabuev and Denisov, 2019), and young people in Western countries are experiencing record high levels of disillusionment with democracy (FT, 2020), the Biden administration's attempts to "renew democracy" (Blinken, 2021) are inevitably doomed to no more than limited success. A hypothetical "Summit

\footnotetext{
This becomes clear if we consider the similarities between the Westphalian system and the capitalist market economy: both systems are based on the existence of multiple competing actors. Competition logic forces actors to prioritize short-term goals, and such prioritization can be justified at the normative, value level only if the reproduction of the entire system is assumed to be unconditional and endless, which eliminates the need for long-term planning.
} 
for Democracy," should it take place, will only make the dividing lines more visible, instead of uniting humanity.

The Russian counter-narrative, which is being articulated by both experts (Karaganov et al., 2020; Karaganov, 2020) and official documents (RF National Strategy, 2021), most consistently singles out two elements: the protection of sovereignty and the preservation of traditional values, in practice often reduced to family values. The problem is that the "do not meddle in our internal affairs" message simply challenges international hegemony, but does not have any positive content of its own, which automatically limits its unifying potential. Moreover, the lack of universality of the Russian family agenda is clearly demonstrated by the case of South Africa which has officially allowed polygamy and is now considering the legalization of polyandry (Fihlani, 2021). In fact, family traditions are too diverse to be a genuine unifying factor.

In such a situation, when constructing "big ideas" it would be wrong to appeal to a certain "normalcy," as Sergei Karaganov (2020) does, or to call for a return to something old. Everything that is old is in question (at least for some people), it cannot justify its own value and cannot become the starting point in building a desired universal consensus. Essentially, this reflects the condition of postmodernity, in which, according to Lyotard, "any consensus <... > must be local" (Lyotard, 1984, p. 66). Therefore, the search for a new unifying idea is largely tantamount to the question of how to overcome postmodernity. But in order to get out of postmodernity-a state of social reality characterized by the inherent multiplicity of value systems and semantic hierarchies (Ibid) - it is necessary to first overcome postmodernism, which is the dominant mentality that legitimizes this social reality today. I say legitimizes because postmodernism criticizes any "big idea" (metanarrative) for building a hierarchy, suppressing alternative meanings and interpretations, and ultimately turning into an instrument of power and oppression (Duignan, 2020).

It seems that the main weakness of such postmodernism is its dependence on a dubious ontological position, according to which there is no single objective reality. If such reality exists, then there is also a 
hierarchy of knowledge that serves as a legitimate basis for authority (which should not always be equated to oppression). Language and social structures can be considered a "game" with arbitrarily set of rules only if you forget that they exist within an external-natural and technological-reality, which is at least partially autonomous from linguistic and social facts. So, when the onset of the Anthropocene reminds us that the history of human societies is not autonomous but integrated with the history of the Earth (Chakrabarty, 2009), it suddenly turns out that "grand narratives are dead, until now" (Hamilton, 2017, p.76).

Furthermore, the ultimate, most radical and undeniable evidence that objective reality, external to the individual or society, exists is death (individual) and extinction (collective). It is this fundamental thought that is expressed by Umberto Eco's seemingly joking remark: "There must be a way in which things are or behave-and the evidence is not only that all men are mortal, but also that if I try to pass through a wall, I break my nose. Death and that wall are the only form of Absolute about which we can be in no doubt" (Eco, 2012/2011, p. 43).

Postmodernity is the extreme degree of indefinite temporality or maybe even the complete "end of temporality" (Jameson, 2003). This is an era that does not even consider the possibility that objective reality can suddenly put an end to its language and social games. Once the possibility of an existential catastrophe is recognized, postmodernism loses any conceptual foundation, thereby opening the intellectual way to overcoming the post-modern era.

\section{HUMAN SURVIVAL AS A FUNDAMENTAL VALUE}

It may seem that the argument has come full circle: we started with existential risks, and we have come back to them. But in fact, considerable analytical work has been done thanks to which existential risks have become not only a problem, but also a solution, or, more precisely, the beginning of a solution. The threat of a global existential catastrophe is a fact of reality, whose correct understanding can provide the basis for a new idea capable of uniting humanity.

The preservation of humanity is an imperative with high unifying potential. Few people will deny the importance of this task. Toby Ord 
convincingly shows that arguments emphasizing the importance of human survival can be found in a variety of moral traditions (Ord, 2020, pp. 42-57). However, the drawback of most current discussions about existential risks is that they regard the survival of humankind as an important value among other values. This is evident, for example, when Ord urges "to establish the pivotal importation of safeguarding humanity, and to place this around the pantheon of causes to which the world devotes substantive attitude and resources. Exactly how substantial remains an open question, but it clearly deserves far more focus than it has received so far" (Ord, 2020, p. 63). Here, survival is an important (perhaps the most important) priority, but still one of many priorities, which makes it possible to ask how much resources and attention can be diverted from other goals for the sake of survival.

This approach, in my opinion, overlooks the key point: the survival of humanity is not just an important value; it is a fundamental value that hierarchically subordinates all others to itself. In other words, the survival of humankind is an ethical Absolute. In this case, the question of resource distribution between survival and other goals is simply meaningless because survival is a reference point for assessing all other purposes and values.

Declaring the survival of humanity an absolute value (that is, in fact, the starting point of ethics) is undoubtedly a radical step that can raise objections. Its full philosophical justification would require a separate article, so here I will give only one argument, which is not final evidence but shows the plausibility of the idea. The survival of humankind is a prerequisite for the realization of all other values, be it freedom, justice, the preservation of traditions, order, equality, human rights, the family, etc. Therefore, this is the only value, the elevation of which to the status of an Absolute can be convincingly and consistently justified: the absolutization of freedom can always be challenged with an appeal to justice, of justice, with an appeal to order, and so on. The absolutization of human survival cannot be disproved in this way, because if people do not survive, there simply will be nothing else. And in a postmodern world, where all old values are in question and relativized, it is the realization of the imperative 
of human survival as an Absolute that can become the starting point in building a new global consensus.

I suggest calling it the "Anthropocene consensus." Only in the Anthropocene era can the survival of humankind finally be fully acknowledged as an absolute value and developed into a full-scale "big idea." This prompts an analogy with the fall of man: a full understanding of good and its free choice are possible only after both good and evil have been experienced. "...the question of how to live with the Earth could ultimately be resolved only after we had developed the power to destroy life on it" (Hamilton, 2017, pp. 124-125). Earlier, until the second half of the 20th century, people, no matter what they did, had too little influence on the level of existential risk to their own existence: under such conditions, it was almost impossible to derive any practical recommendations from the imperative of human survival. However, with the advent of the Anthropocene era, it has become obvious that human actions, no matter how local and insignificant, have consequences for the survival of humankind. Moreover, this applies to value systems and forms of social organization: they are unequal in terms of their impact on the prospects for the survival of the human race and can be assessed accordingly. As a result, the responsibility of humankind for its own survival has now become a fully meaningful and tangible concept.

What does the "Anthropocene consensus" imply in practice? A detailed comparative study of different values and socio-political systems in terms of their impact on the prospects for human survival requires separate extensive research, so the rest of this section should be viewed rather as a preliminary outline for the analysis of the problem.

Firstly, the Anthropocene consensus implies identifying immediate, most urgent existential threats and taking action to prevent them. A rough list of threats was given at the beginning of this article. So, here I will highlight one important conceptual point: existential risks (as well as ways of reducing them) should be considered in their entirety and interconnection, because an isolated analysis of each threat separately can lead to incorrect conclusions. For instance, rejection of advanced technology could seem the right strategy to avoid anthropogenic 
existential risks, but taking into account natural risks, the need for a high level of technological development becomes obvious. Similarly, human activities in space should also be considered in the broadest possible context: if you evaluate space activities in isolation, they appear as a necessary and urgent measure to increase the resilience of humankind in the event of a global disaster on Earth. However, taking into account the entire range of consequences, this may be a senseless undertaking for the time being, as it will only divert much-needed resources and attention from other problems, and still will not yet be able to create stable and self-sustaining colonies (Deudney, 2020; Ord, 2020, p. 394).

Secondly, in light of the Anthropocene consensus, sovereignty appears as an important, but not absolute, principle of the international political order. A sovereign nation-state remains the main source of identity for many people around the world, and for this reason it is impossible to imagine the principle of sovereignty abandoned in the foreseeable future. However, as in the case of human relations in society, a state's sovereign freedom is limited by responsibility: when you bear part of the responsibility for universal survival, the interest of others in your internal affairs is quite legitimate. The key task is to find such forms of expressing this interest that would privilege dialogue and strictly limit the use of force. Here it may be extremely appropriate to further develop the half-forgotten concept of "sovereignty as responsibility," applying it not only (and not so much) to armed interventions, but to a wider range of issues.

The domestic political structure of the state also has to be recognized as a legitimate subject of external concern in an era of global existential threats. At the same time, the Anthropocene consensus allows, at least theoretically, for different political regimes, depending on specific historical circumstances. For instance, conceptual arguments are possible both in favor of democracy and in favor of authoritarianism: A) abrupt external changes require autocratic methods of governance, because democracy is better suited for maintaining the status quo and adapts too slowly (Koktysh, 2019, pp. 141-142); B) the bigger, the more complex and diverse the society, the less effective the authoritarian 
political model is, as it blocks feedback channels and reduces the effectiveness of social learning (Marshall and Elzinga-Marshall, 2017, pp. 7-8). What is important is that the Anthropocene consensus shows that no political regime can justifiably claim to be of absolute value, which creates room for conducting dialogue and overcoming irreconcilable confrontation.

Thirdly, as Robert Cox noted, in order to be able to survive, the world order must be just (Cox, 2008). High levels of inequality, both global and national, increase the likelihood of social crises and conflicts, and deprive humanity of a large share of human potential needed for averting existential threats (Stiglitz, 2012).

Fourthly, and finally, the Anthropocene consensus makes one think again about the relationship between global and national dimensions of security. For many large social groups, especially large states, the most likely extinction scenario today is a global catastrophe, not some isolated national collapse. This raises serious questions about the discourse of great-power competition, which is regaining popularity once again, since the "security" which it promises (protection from external aggression by other states) may turn into absolute vulnerability in the face of global threats of the Anthropocene era.

\section{UTOPIA AND REALITY}

When presenting a new big idea we cannot overlook the question of how realistic it is. Is it reasonable to expect the Anthropocene consensus to succeed?

If we talk about the success of the idea itself, then it seems that the chances of the Anthropocene consensus to gain recognition and traction among intellectual circles are fairly high. It is quite in line with the intellectual zeitgeist: the topic of existential risks and human survival has recently gained popularity in various fields of knowledge: from natural sciences (for example, the aforementioned concept of planetary boundaries) to international relations (Sears, 2021). Earlier works on global survival written in the 1980s-1990s, for example, by Jonathan Schell (1982) and John Herz (2003) are getting a new lease on life (van Munster and Sylvest, 2021; Stevens, 2018). Some 
narrower areas of research, for example, nuclear ethics (Doyle, 2020) and Earth System Governance (Biermann, 2014) also deal with the same issue. Anthropocene studies, on the one hand, and existential risk studies, on the other, emerge as holistic interdisciplinary (or even post-disciplinary) research fields, as evidenced by the emergence of specialized journals (The Anthropocene Review) and research centers (Future of Humanity Institute, Centre for the Study of Existential Risk). Human survival and the threat of existential catastrophe increasingly become a subject of reflection in moral philosophy (Parfit, 1984; Jonas, 1984/1979: Leslie, 1996) and political theology (Keller, 2018).

Finally, going beyond the "spirit of the time," it would be worth noting that some of the Anthropocene consensus ideas were foreseen by earlier thinkers. In Russia, Vladimir Vernadsky stands out for his theory of the biosphere which largely laid the foundation of Earth System Science and, therefore, of the understanding of the Anthropocene that developed within it (Steffen et al., 2020). If the aforementioned analogy between the onset of the Anthropocene and the fall of man is to be taken seriously, then parallels with the Christian theological tradition also become obvious, in particular, between the imperative of human survival and the idea of theosis (deification) elaborated by the Eastern Fathers of the Church (Averintsev, 2006).

The proposed Anthropocene consensus intersects with all of the above intellectual trends, thus becoming "discursively recognizable" for each of them. At the same time, it goes further and claims not only to incorporate elements from individual areas of research, but to synthesize these areas into one whole, thereby creating a single, hierarchically structured intellectual and practical paradigm. This can be achieved precisely by postulating the survival of humanity as an ethical Absolute, the point of assembly where all other ideas converge and from which they all emanate.

Moreover, there is real demand for such a universal idea. Now that "the general narrative of global development and of the model of the future is lost but still needed if not by all people on Earth, then at least by a sizeable majority" (Bystritsky, 2021), and there is a sense 
of "moral inadequacy of existing political models" (Barabanov et al., 2020, p. 11), the demand for a new metanarrative emerges naturally. In Russia, the discussion about the "big idea" for the country in general and its foreign policy in particular, that took place over the past year (Karaganov et al., 2020; SVOP, 2020), indicates that such demand exists at least among the intellectual circles.

If we go from ideas to practical implementation, the picture becomes more complex, but not at all hopeless. Decision-making bodies (both national governments and international organizations) already become increasingly concerned about global existential threats and the survival of humanity. In 1997, the Declaration on the Responsibilities of the Present Generations Towards Future Generations stated: "The present generations should strive to ensure the maintenance and perpetuation of humankind..." (UNESCO, 1997), with the latest UNDP report recognizing the need to rethink development in the face of the Anthropocene (UNDP, 2020). In his article in Foreign Affairs, Joe Biden names climate change, nuclear weapons, and disruptive technologies-the most important elements of the Anthropocene consensus agenda-as the main global problems that require a collective solution (Biden, 2020). China's "community with a shared future for mankind" also has much in common with the Anthropocene consensus. Similar considerations can be found in Russian official documents: "one of the main tasks facing humankind in the 21 st century is the creation of conditions, guarantees and prospects for the harmonious development of future generations"3 (CSTO, 2020).

The same concern about the preservation of humankind, though related to a specific_-nuclear-realm, was also voiced in the recent U.S.-Russia Presidential Joint Statement on Strategic Stability, in which the parties reaffirmed "the principle that a nuclear war cannot be won and must never be fought" and announced their decision to "embark together on an integrated bilateral Strategic Stability Dialogue in the

This wording rather echoes the concept of sustainable development. The question may arise: Is the Anthropocene consensus so much different from the idea of sustainable development to succeed where the latter failed? It seems that the key difference is in how much emphasis is put on finite temporality and on human survival. Sustainable development generally retains a modernist orientation towards endless progress. 
near future" (U.S.-Russia Statement, 2021). Finally, studies show that climate change has become one of the most important global priorities precisely after the threat posed by it was recognized as potentially existential (Allan, 2017). If such narrower ideas were able to motivate practical action, there is every reason to expect the same from the Anthropocene consensus.

The idea of the Anthropocene consensus may receive an additional impetus at the national and international levels if actively supported by civil society. In fact, the demand for a new metanarrative is just as strong in it as it is in intellectual circles, and the survival agenda can be quite attractive rhetorically, as borne out by the spread of Extinction Rebellion movement in many countries. But there are also risks: the masses easily turn any idea into a utopia, as evidenced, in particular, by the outbreak of millenarian sentiment in many countries amid the pandemic (Kuznetsov, 2020). Will the Anthropocene consensus turn into another utopia that justifies mass sacrifices in the name of its implementation?

A safeguard in this case is the very logic of the Anthropocene consensus which is fundamentally not utopian. Utopia unfolds in a paradigm where, firstly, there is a certain ideal state of man and society and, secondly, the desire to achieve this state by transcending "the bonds of the existing order" (Mannheim, 1954, p.173). As was shown above, in the case of the Anthropocene consensus, an ethical Absolute is formulated not as some kind of positive state, but through negation, as non-extinction of humanity. Therefore, there is no ideal "wonderful future" that can justify the temptation to make a bloody leap into it. There is only the task of preserving humanity, which may require different measures, but certainly not destructive revolutions.

At the same time, it should be emphasized that the Anthropocene consensus is not an unequivocally conservative idea. Since in this paradigm the purpose of social organization is to prevent existential threats to humanity, and the existential threats themselves are not a static phenomenon, but the product of a dynamic, developing reality (natural and technological), therefore, development - intellectual, moral, institutional, scientific-is also necessary to counter these threats. 
Therefore, the Anthropocene consensus makes the elites of different countries confront an important question about the drawbacks and limits of social and political conservatism. Sometimes (for example, in the case of today's Russia) it seems that the conservative course is perceived by the country's leadership as relatively unproblematic. But is it sustainable? Do conservative and restrictive measures designed to prevent social unrest in the short term (and generally effective in this regard) not lead to the "anabiosis" of the system, block feedback channels between the authorities and society, and exacerbate social problems? What are the limits of conservative politics? There can be different answers to these questions, but it is necessary to raise and reflect on them most seriously.

\section{NATIONAL STRATEGY FOR THE ANTHROPOCENE ERA}

In conclusion, it would make sense to describe, albeit sketchily, what an Anthropocene-consensus-inspired strategy of a single country should look like. It takes coordinated international action to effectively counter global existential threats, but in today's realities, it is national policies that should become the building blocks of a joint global effort. To avoid being biased, I will use Russia as an example, however, the thoughts below are rather general, and therefore most of them are theoretically applicable to many countries.

So, what a country should do in the Anthropocene era?

Firstly, assume a responsible position in areas that are most closely related to current existential risks: nuclear weapons, environment, emerging technologies; adopt a strictly defensive nuclear strategy; make a commitment to the principle of strategic stability (in this regard, Russia's policy is generally consistent with the Anthropocene consensus requirements); reduce $\mathrm{CO}_{2}$ emissions (positive changes have been made in the past year); take a cautious approach to research in the field of artificial intelligence and biotechnology, and put forward initiatives to regulate breakthrough technologies internationally in order to prevent a regulatory race to the bottom.

Secondly, adopt an approach to internal development that would take into account both the historical legacy and distinct characteristics 
of society and the common global goal of ensuring the sustainability and survival of humanity; avoid unstably high levels of social inequality, as well as maintain the ability of society to detect and address emerging problems in a timely manner.

Thirdly, seek to establish a practical dialogue, based on the Anthropocene consensus, on the social and political principles of the world order. Agreeing to adopt the principle of responsibility for controlling potential hotbeds of epidemics could become the first step towards broadening the "sovereignty as responsibility" concept. Russia could initiate a universal Anthropocene Summit to discuss these issues.

Many of the above thoughts are far from new, but the Anthropocene consensus, based on the understanding of human survival as an ethical Absolute, gives them additional justification, and in the future may also highlight new nuances that have not been noticed so far.

A pessimist could say that the implementation of the Anthropocene consensus would require both Russia and other countries to make radical changes in many areas. But if we do not change for the sake of human survival and the existence of future generations, then why change at all?

\section{References}

Allan, B. B., 2017. Second Only to Nuclear War: Science and the Making of Existential Threat in Global Climate Governance. International Studies Quarterly, 61(4), pp. 809-820.

Averintsev, S.S., 2006. Sofia-Logos. Slovar' [Sophia-Logos. A Dictionary]. Kyiv: Dukh i litera.

Barabanov, O. et al., 2020. Utopia mnogoobraznogo mira: kak prodolzhayetsa istoria [Utopia of a Diverse World: How History Continues]. Valdai Discussion Club, October [online]. Available at: https://ru.valdaiclub.com/files/35332/ [Accessed 15 May 2021].

BBC, 2021. China’s Xi Declares Victory in Ending Extreme Poverty. BBC News, 25 February [online]. Available at: https://www.bbc.com/news/world-asiachina-56194622 [Accessed 19 July 2021]. 
Biden J.R., Jr., 2020. Why America Must Lead Again. Foreign Affairs, 99(2) [online]. Available at: https://www.foreignaffairs.com/articles/unitedstates/2020-01-23/why-america-must-lead-again [Accessed 15 May 2021].

Biermann, F., 2014. Earth System Governance: World Politics in the Anthropocene. Cambridge, MA: The MIT Press.

Blinken, A., 2021. A Foreign Policy for the American People. Speech by Antony J. Blinken, Secretary of State, 3 March [online]. Available at: https://www.state. gov/a-foreign-policy-for-the-american-people/ [Accessed 15 May 2021].

Bostrom, N., 2013. Existential Risk Prevention as Global Priority. Global Policy, 4(1), pp. 15-31.

Bystritsky, A., 2021. Na puti k prekrasnomu budushchemu [On the Way to a Beautiful Future]. Valdai Discussion Club, 11 March [online]. Available at: https://ru.valdaiclub.com/a/chairman-speech/na-puti-k-prekrasnomubudushchemu/ [Accessed 15 May 2021].

Chakrabarty, D., 2009. The Climate of History: Four Theses. Critical Inquiry, 35(2), pp. 197-222. doi:10.1086/596640.

Cox, R., 2008. The Point Is Not Just to Explain the World But to Change It. In: C. Reus-Smit and D. Snidal (eds.) The Oxford Handbook of International Relations. Oxford: Oxford University Press, pp. 84-93.

Cramer, M., 2021. Doomsday Clock Says World Remains '100 Seconds' from Disaster. The New York Times, 27 January [online]. Available at: https://www. nytimes.com/2021/01/27/us/doomsday-clock-midnight.html [Accessed 19 July 2021].

CSTO, 2020. Zayavlenie Soveta kollektivnoi bezopasnosti Organizatsii Dogovora o kollektivnoi bezopasnosti o formirovanii spravedlivogo i ustoichivogo miroustroistva [A Statement by the Collective Security Council of the Collective Security Treaty Organization on Shaping a Fair and Sustainable World Order]. Collective Security Treaty Organization, 2 December [online]. Available at: https://odkb-csto.org/documents/statements/zayavlenie-soveta-kollektivnoybezopasnosti-organizatsii-dogovora-o-kollektivnoy-bezopasnosti-o-form/ [Accessed 15 May 2021].

Deudney, D., 2020. Dark Skies: Space Expansionism, Planetary Geopolitics, and the Ends of Humanity. Oxford: Oxford University Press.

Doyle, T. E. II, 2020. Nuclear Ethics in the Twenty-First Century: Survival, Order, and Justice. London, NY: Rowman \& Littlefield Publishers. 
Duignan, B., 2020. Postmodernism. Encyclopedia Britannica [online]. Available at: https://www.britannica.com/topic/postmodernism-philosophy [Accessed 19 July 2021].

Eco, U., 2012/2011. Inventing the Enemy and Other Occasional Writings. Trans. by Richard Dixon. NY: Houghton Mifflin Harcourt.

Ellis, E.C., 2018. Anthropocene: A Very Short Introduction. Oxford: Oxford University Press.

Fihlani, P., 2021. Outcry over South Africa's Multiple Husbands Proposal. BBC News [online]. Available at: https://www.bbc.com/news/world-africa-57548646 [Accessed 19 July 2021].

Foucault, M., 2009/2004. Security, Territory, Population: Lectures at the College de France 1977-78. Trans. Graham Burchell. Palgrave Macmillan.

FT, 2020. The Young's Discontent with Democracy Is Worrying. The Financial Times, 23 October [online]. Available at: https://www.ft.com/content/53fc1c4a7ca3-4406-b9db-bebf1af9c9b8 [Accessed 20 July 2021].

Gabuev, A., Denisov, I., 2019. Vzyaty v plenum. Kak prodvigaetsa tranzit vlasti v Kitae [Accepted into the Plenum. How Is Power Transition in China Proceeding?]. Carnegie Moscow Center, 5 November [online]. Available at: https://carnegie.ru/commentary/80265 [Accessed 15 May 2021].

Global Challenges Foundation, 2016. Global Catastrophic Risks 2016. The Global Challenges Foundation \& The Global Priorities Project [online]. Available at: https://globalchallenges.org/wp-content/uploads/2019/07/Global-CatastrophicRisk-Annual-Report-2016.pdf [Accessed 19 July 2021].

Global Priorities Project, 2017. Existential Risk: Diplomacy and Governance. The Future of Humanity Institute [online]. Available at: http://www.fhi.ox.ac.uk/ wp-content/uploads/Existential-Risks-2017-01-23.pdf [Accessed 19 July 2021].

Habermas, J., 1987/1985. The Philosophical Discourse of Modernity. Trans. By Frederick Lawrence. Cambridge: Polity Press.

Hamilton, C., 2017. Defiant Earth: The Fate of Humans in the Anthropocene. Cambridge: Polity Press.

Hamilton, S., 2018. Foucault's End of History: The Temporality of Governmentality and Its End in the Anthropocene. Millennium: Journal of International Studies, 46(3), pp. 371-395.

Herz, J., 1957. Rise and Demise of the Territorial State. World Politics, 9(4), pp. 473-493. 
Herz, J., 2003. On Human Survival: Reflections on Survival Research and Survival Policies. World Futures, 59(3-4), pp. 135-143.

Interim National Security Strategic Guidance, 2021. The White House, March [online]. Available at: https://www.whitehouse.gov/wp-content/ uploads/2021/03/NSC-1v2.pdf [Accessed 15 May 2021].

Jameson, F., 2003. The End of Temporality. Critical Inquiry, 29(4), pp. 695-718.

Jervis, R., 1989. The Meaning of the Nuclear Revolution: Statecraft and the Prospect of Armageddon. Ithaca: Cornell University Press.

Jonas, H., 1984/1979. The Imperative of Responsibility: In Search of an Ethics for the Technological Age. Chicago: The University of Chicago Press.

Karaganov, S., 2020. Nastuplenie v voine idei [An Offensive in the War of Ideas]. Rossiya v globalnoi politike, 27 November [online]. Available at: https:// globalaffairs.ru/articles/nastuplenie-v-vojne-idej/ [Accessed 15 May 2021].

Karaganov, S. et al., 2020. Zashchita mira, zemli, svobody vybora dlya vsekh stran: Novye idei dlya vneshnei politiki Rossii [Protection of Peace, Earth and Freedom of Choice for All the Countries: New Ideas for Russian Foreign Policy]. HSE Report [online]. Available at: https://www.hse.ru/data/2020/04/ 27/1544981528/\%D0\%97\%D0\%B0\%D1\%89\%D0\%B8\%D1\%82\%D0\%B0\%20 \%D0\%BC\%D0\%B8\%D1\%80\%D0\%B0.pdf [Accessed 15 May 2021].

Keller, C., 2018. Political Theology of the Earth: Our Planetary Emergency and the Struggle for a New Public. NY: Columbia University Press.

Koktysh, K.E., 2019. Teoria metafory i politicheskie instituty [The Metaphor Theory and Political Institutions]. Moscow: Izdatelstvo "MGIMO-Universitet".

Kuznetsov, G., 2020. Protest poslednikh dnei: Covid-eskhatologya i ulichnaya politika ot Sietla do Khabarovska [Protests of the Last Days: COVIDEschatology and Street Politics from Seattle to Khabarovsk]. Carnegie Moscow Center, 4 August [online]. Available at: https://carnegie.ru/commentary/82418 [Accessed 20 July 2021].

Latour, B., 2017. Facing Gaia: Eight Lectures on the New Climatic Regime. Cambridge: Polity Press.

Leslie, J., 1996. The End of the World: The Science and Ethics of Human Extinction. London, NY: Routledge.

Lyotard, J.-F., 1984/1979. The Postmodern Condition: A Report on Knowledge. Trans. by Geoffrey Bennington and Brian Massumi. Minneapolis: University of Minnesota Press. 
Mannheim, K., 1954. Ideology and Utopia: An Introduction to the Sociology of Knowledge. Trans. by Louis Wirth and Edward Shils. NY: Harcourt, Brace \& Co. Inc.; London: Routledge \& Kegan Paul Ltd.

Marshall, M.G. and Elzinga-Marshall, G.C., 2017. Global Report 2017: Conflict, Governance, and State Fragility. Center for Systemic Peace [online]. Available at: http://www.systemicpeace.org/vlibrary/GlobalReport2017.pdf [Accessed 15 May 2021].

Ord, T., 2020. The Precipice: Existential Risk and the Future of Humanity. NY: Hachette Books.

Parfit, D., 1984. Reasons and Persons. Oxford: Oxford University Press.

RF National Strategy, 2021. Strategia natsionalnoi bezopasnosti Rossiiskoi Federatsii [National Security Strategy of the Russian Federation]. Kremlin.ru, 2 July [online]. Available at: http://static.kremlin.ru/media/events/files/ru/QZw 6hSk5z9gWq0plD1ZzmR5cER0g5tZC.pdf [Accessed 19 July 2021].

Rockström, J. et al., 2009. A Safe Operating Space for Humanity. Nature, 461(7263), pp. 472-475. DOI: 10.1038/461472a.

Safranchuk, I.A., 2020. Globalization and the Decline of Universalism: New Realities for Hegemony. In: P. Dutkiewicz, T. Casier, J.A. Scholte (eds.) Hegemony and World Order: Reimagining Power in Global Politics. London: Routledge, pp. 65-77.

Safranchuk I.A. and Lukyanov F.A., 2021. Sovremenny mirovoi poryadok: strukturnye realii i sopernichestvo velikikh derzhav [The Modern World Order: Structural Realities and the Great Powers' Rivalry]. Polis. Political Studies, 3, pp. 57-76. DOI: https://doi.org/10.17976/jpps/2021.03.05.

Schell, J., 1982. The Fate of the Earth. New York: Knopf.

Sears, N.A., 2021. International Politics in the Age of Existential Threats. Journal of Global Security Studies, 6(3), pp.1-23.https://doi.org/10.1093/jogss/ogaa027.

Sewell, W.H., Jr., 2008. The Temporalities of Capitalism. Socio-Economic Review, 6(3), pp. 517-537.

Steffen et al., 2020. The Emergence and Evolution of Earth System Science. Nature Reviews Earth \& Environment, 1(1), pp. 54-63. DOI: https://doi. org/10.1038/s43017-019-0005-6.

Stevens, T., 2018. Exeunt Omnes? Survival, Pessimism and Time in the Work of John H. Herz. Millenium: Journal of International Studies, 46(3), pp. 283-302. 
Stiglitz, J.E., 2012. The Price of Inequality: How Today's Divided Society Endangers Our Future. New York: W.W. Norton \& Company.

SVOP, 2020. S Rossiei mir luchshe, chem bez neyo? XVIII Assambleya Soveta po vneshnei i oboronnoi politike [Is the World Better with Russia than Without It? 18th Assembly of the Council on Foreign and Defense Policy]. Rossiya $v$ globalnoi politike, 16 December [online]. Available at: https:/globalaffairs.ru/ articles/s-rossiej-mir-luchshe/ [Accessed 15 May 2021].

UK Treasury, 2006. Stern Review on the Economics of Climate Change [online]. Available at: https://web.archive.org/web/20081231020412/http://www.hmtreasury.gov.uk/d/Chapter_2_Technical_Annex.pdf [Accessed 19 July 2021].

UNDP, 2020. Human Development Report 2020: The Next Frontier: Human Development and the Anthropocene. United Nations Development Programme [online]. Available at: http://hdr.undp.org/sites/default/files/hdr2020.pdf [Accessed 15 May 2021].

UNESCO, 1997. Declaration on the Responsibilities of the Present Generations Towards Future Generations. United Nations Educational, Scientific and Cultural Organization, 12 November [online]. Available at: http://portal.unesco.org/en/ ev.php-URL_ID=13178\&URL_DO=DO_TOPIC\&URL_SECTION=201.html [Accessed 20 July 2021].

U.S.-Russia Statement, 2021. U.S.-Russia Presidential Joint Statement on Strategic Stability. The White House, 16 June [online]. Available at: https:// www.whitehouse.gov/briefing-room/statements-releases/2021/06/16/u-s-russiapresidential-joint-statement-on-strategic-stability/ [Accessed 20 July 2021].

van Munster, R. and Sylvest, C., 2021. Nuclear Weapons, Extinction, and the Anthropocene: Reappraising Jonathan Schell. Review of International Studies, 47(3), pp. 294-310. https://doi.org/10.1017/S0260210521000061.

Zalasiewicz, J. et al. (eds.), 2019. The Anthropocene as a Geological Time Unit: A Guide to the Scientific Evidence and Current Debate. Cambridge: Cambridge University Press. 